\title{
NOVEL GEOBACILLUS THERMOLEOVORANS KNG 112 THERMOPHILIC BACTERIA FROM BANDARU HOT SPRING: A POTENTIAL PRODUCER OF THERMOSTABLE ENZYMES
}

\author{
KOTRESH KR ${ }^{1}$, SHIVAYOGEESWAR NEELAGUND ${ }^{2 *}$, GURUMURTHY DM ${ }^{3}$ \\ ${ }^{1}$ Department of Biochemistry, Kuvempu University, Shimoga, Karnataka, India. ${ }^{2}$ Department of Studies and Research in Biochemistry, \\ Kuvempu University, Shimoga, Karnataka, India. ${ }^{3}$ Department of Biotechnology, GM Institute of Technology, Davanagere, Karnataka, India. \\ Email: neelgund@kuvempu.ac.in
}

Received: 09 October 2019, Revised and Accepted: 19 November 2019

ABSTRACT

Objectives: Herein, industrial important thermostable bacteria and their thermozymes have been studied for their relative resistance to the various harsh environments. The façade nature of amylase was studied by partial optimization from a novel Geobacillus strain indicates that the enzymes may be potential candidates for industrial biocatalyst.

Methods: Routine microbiological methods have employed for the isolation of novel Geobacillus strain from hot springs. The strain was further characterized by various phenotypic and genotypic methods, such as 16s rRNA gene sequencing methods. Furthermore, the strain was partially optimized for the production of thermostable amylase enzymes such as various temperatures, pH, carbon sources, substrate concentration, and agitation speed.

Results: A Gram-positive, aerobic, and non-motile Geobacillus sp. were isolated and characterized from a hot spring of Karnataka. Various biochemical tests for the strain IC5 revealed that the bacteria are capable of growing at the temperature $55^{\circ} \mathrm{C}$ and $\mathrm{pH} 7-8$. These tests also revealed that the strain IC5 also tolerated $8 \%(\mathrm{w} / \mathrm{v}) \mathrm{NaCl}$ and has amylolytic and lipolytic enzyme activities. Furthermore, the $16 \mathrm{~S}$ rRNA gene sequence of the strain indicated that the strain IC5 belongs to the genus Geobacillus was in close resemblance with the gene of Geobacillus thermoleovorans EC-5 with $99 \%$ of similarities. The partial optimization and characteristics of G. thermoleovorans $\mathrm{KNG} 112$ amylase were shown the optimum activity at $50^{\circ} \mathrm{C}-60^{\circ} \mathrm{C}$ and $\mathrm{pH}$ 8. The strain used starch as a carbon source with an agitation speed of 120rpm for maximal amylase production.

Conclusion: The present study on G. thermoleovorans KNG 112 revealed that the bacteria could withstand harsh environmental conditions and capable of producing critical industrial thermozymes such as amylase and lipase.

Keywords: Amylase, Lipase, Thermophilic, Geobacillus thermoleovorans, Phylogenetic.

(C) 2020 The Authors. Published by Innovare Academic Sciences Pvt Ltd. This is an open access article under the CC BY license (http://creativecommons. org/licenses/by/4. 0/) DOI: http://dx.doi.org/10.22159/ajpcr.2020.v13i1.36008

\section{INTRODUCTION}

Microbiological exploration of hot springs has bought a paradigm shift in both science and society in general. Globally, it is regarded as one of the most rewarding studies that established a good microbial arsenal of human knowledge [1,2]. It has enriched our scientific knowledge of understanding toward thermophilic lifestyles and also provided a number of biological resources having potential industrial applications that require processing at harsh conditions, including high temperature and $\mathrm{pH}[3,4]$.

Hot springs were arisen by the emergence of geothermally heated groundwater in volcanically active regions [5]. Hot springs were found throughout the world but they are more concentrated only in certain regions of the world. Hot springs vary widely in their temperature, chemical composition, and $\mathrm{pH}$ [6]. Worldwide, geothermal areas which are favorable habitats for thermophilic organisms were limited to a restricted number of sites in New Zealand [8], Jordan [9], United States [10], Italy [11], and Turkey [12]. In India, nearly 400 thermal springs under seven geothermal provinces were distributed [13].

Thermophilic bacilli were grown at a temperature from $45^{\circ} \mathrm{C}$ to $70^{\circ} \mathrm{C}$ and these were possible isolates from different environmental conditions such as hot springs, cold habitats, petroleum reservoirs, deep ocean-basin cores, and deep sea hydrothermal vents [14]. Thermophilic bacteria were first characterized by Miquel which was found to form aerobic spore and able to grow at $70^{\circ} \mathrm{C}$ [15] and also many thermophilic bacteria have been characterized [16]. The most important characteristic of thermophilic organisms is their ability to produce thermostable enzymes with higher operational stability and longer shelf life [17]. Among bacterial sources, several strains of Bacillus and Geobacillus were exploited for thermostable $\alpha$-amylase production in industries $[18,19]$.

$\alpha$-Amylases (EC 3.2.1.1, 1,4- $\alpha$-D-glucanglucanohydrolyase) hydrolyze starch to a range of products such as glucose and maltose or specific maltooligosaccharide or mixed maltooligosaccharides [20,21]. Amylase can be obtained from several bacteria, yeast, fungi, and actinomycetes; however, enzyme from bacterial and fungal sources has dominated applications in industries [22]. They were employed in industries for various purposes such as glucose and maltose-forming $\alpha$-amylases in alcohol fermentation and sugar syrup formulation and maltooligosaccharide forming $\alpha$-amylases in food processing [23,24]. Amylases also play a significant role in starch, detergent, beverage, and textile industries and their commercial production from microorganisms represent $25 \%-33 \%$ of the world enzyme market [25]. Industrial production of enzymes can be made economical by utilizing low cost substrates such as agricultural byproducts in the production medium [26].

Microbial lipases have also been immensely used for biotechnological applications in dairy, detergents, and textile industries as well as surfactant and oil-processing industries. In fact, they were also been widely used in pharmaceutical industries in the production of enantiomerically pure chemicals, since they have a number of unique characteristics, coupled with in distinct substrate specificity [27], stable, and active in organic 


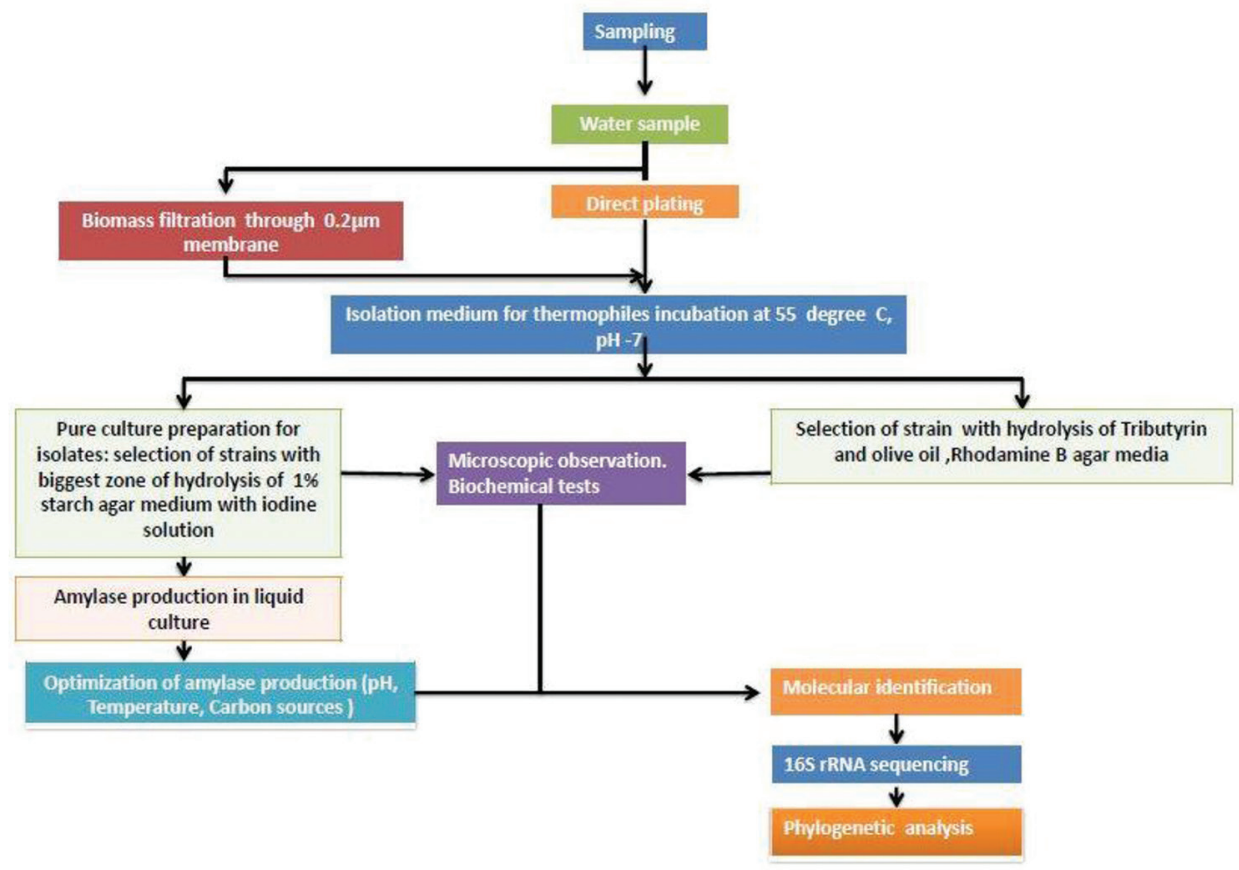

Fig. 1: Detailed flow chart of bacterial isolation, identification, and screening for amylase production and its optimization

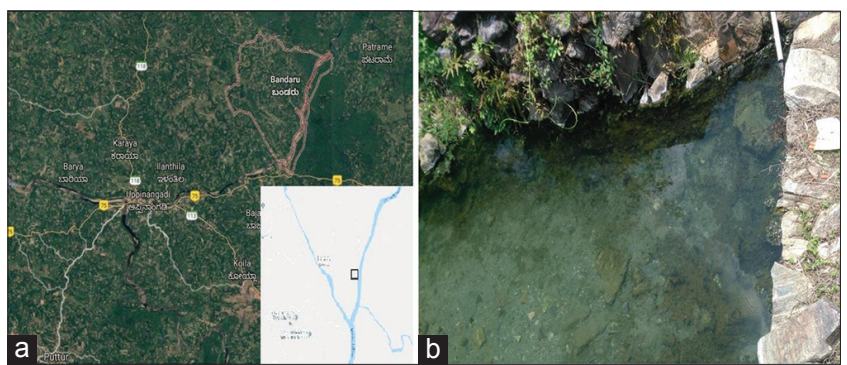

Fig. 2: (a) Map showing the location of hot water spring in Karnataka, India, (b) sampling site

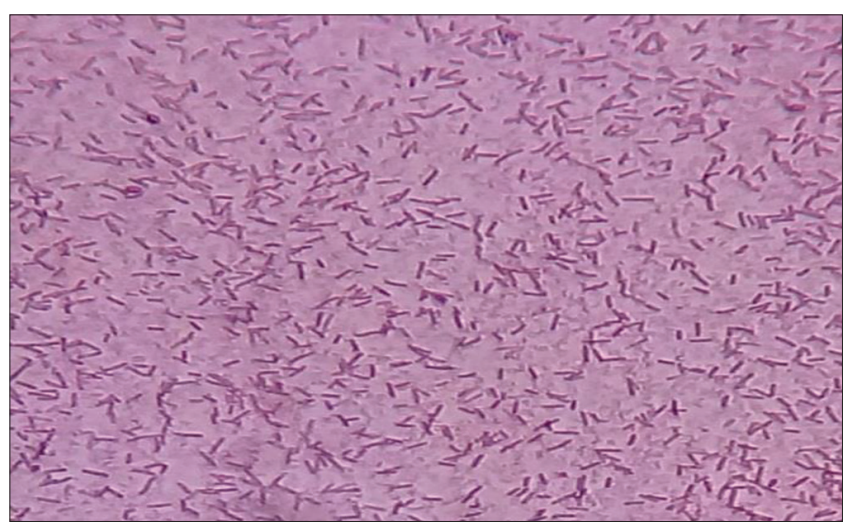

Fig. 3: Microscopic image of newly isolated Geobacillus species from Bandaru hot spring

solvents [28]. They do not require cofactors [29], exhibit a high degree of regioselectivity, and possess a wide range of substrate specificity for the conversion of various unnatural substrates [30].

Present work envisages the isolation and characterization of amylase and lipase producing bacteria, from natural source "Bandaru” hot Spring in Karnataka. This work describes the effects of culture conditions on amylase production in submerged fermentation under controlled conditions of carbon sources, temperature, $\mathrm{pH}$, starch concentration, and agitation speed in a laboratory shaking incubator.

\section{METHODS}

Source of strain and media

Water sample was collected from hot water springs located on the bank of river Nethravathi (Belthangady taluk), Dakshina Kannada district, Karnataka state, India. The temperature and $\mathrm{pH}$ of the thermal water were recorded immediately after sampling. One milliliter of water sample was serially diluted in saline $(0.9 \% \mathrm{NaCl})$ and plated onto solid PBTA media containing (peptone $1.5 \%$, beef extract $0.2 \%$, tryptone $0.5 \%, \mathrm{NaCl} 0.1 \%$, and agar $2 \%$ ). Plates were sealed with parafilm and incubated at $60^{\circ} \mathrm{C}$ for $12 \mathrm{~h}$ to identify possible microorganism existing in the water samples. The various colonies were picked, isolated in pure culture and then stored at $-20^{\circ} \mathrm{C}$.

\section{Chemicals}

All chemicals were purchased from HiMedia Laboratories, Mumbai. Tryptone was procured from Rasayan laboratories.

\section{Screening of amylase and lipase producing bacteria} Screening of amylolytic bacteria using starch

The amylase production of the isolates was determined by subculturing in SYPB media, which contains $2 \%$ starch, $1 \%$ yeast extract, $0.1 \%$ peptone, $0.1 \%$ beef extract, $0.05 \% \mathrm{MgSO}_{4}, 0.04 \% \mathrm{CaCl}_{2}$, and $\%$ agar, $\mathrm{pH}-7$ [31]. The plates were incubated at $60^{\circ} \mathrm{C}$ for $24 \mathrm{~h}$. An appearance of clear zone around the colonies after flooding 1\% iodine solution indicates the amylase activity of the isolates. Among those, the bacteria showing higher amylase activity were selected for further amylase enzyme production.

\section{Screening of lipolytic bacteria using tributyrin}

The lipase producing bacteria screening was performed in Petri dishes using medium constituted by $0.5 \%$ peptone, $0.3 \%$ yeast extract, $0.1 \%$ tributyrin, and $2 \%$ agar at $\mathrm{pH} 7.0$ [32]. The isolated pure cultures were inoculated and plates were incubated at $60^{\circ} \mathrm{C}$ for $24 \mathrm{~h}$. After incubation, a clear lipolytic halo appeared around the colonies. The isolated strains which displayed higher halos were selected as promising bacterial lipase producers using tributyrin as substrate. 
Screening of lipolytic bacteria using Rhodamine B olive oil

The isolated bacteria were screened for lipolytic activity using tributyrin in Petri dishes using medium consists of nutrient broth, $0.8 \%$; $\mathrm{NaCl}, 0.4 \%$ and agar-agar $2 \%$ at $\mathrm{pH}-7$. The medium was autoclaved and cooled till $60^{\circ} \mathrm{C}$. Then, $3 \%$ olive oil and $1 \mathrm{ml}$ of Rhodamine B $(1 \mathrm{mg} / \mathrm{ml})$ were added [33]. The medium was thoroughly shake and spread onto Petri dishes, later bacterial strains were inoculated and incubated at $60^{\circ} \mathrm{C}$ for $48 \mathrm{~h}$. The extracellular lipase enzyme production was identified as an orange fluorescent halo under ultraviolet (UV) light at $350 \mathrm{~nm}$.

\section{Biochemical and physiological characterization of isolate}

Bacterial growth was determined by measuring the $\mathrm{OD}_{600}$ (Eppendorf Biospectrometer, Germany) in liquid media. Effect of temperature on bacterial growth was analyzed in PBT liquid broth media, between 40 and $90^{\circ} \mathrm{C}$. The effect of salinity was determined; various amounts of $\mathrm{NaCl}$ were directly weighed to a $25 \mathrm{ml}$ medium with the desired $\mathrm{NaCl}$ concentration $(0 \%-1 \%)$ at $55^{\circ} \mathrm{C}$. For effect of $\mathrm{pH}$, the medium was adjusted with $5 \mathrm{M} \mathrm{HCl}$ or $10 \mathrm{M} \mathrm{NaOH}$ (in 0.5 -unit steps) to obtain $\mathrm{pH}$ values ranging from 4 to 12 and recorded after 3 days at $55^{\circ} \mathrm{C}$. The isolate was determined by conducting fermentation of D-cellobiose, D-xylose, D-galactose, glycerol, inositol, and D-lactose. The hydrolysis of starch, tributyrin, gelatin, casein and utilization of citrate, and acetate was also determined. Gram's reaction was determined using the HiMedia Gram Stain Kit according to the manufacturer's instructions.

\section{Sequencing and phylogenetic analysis}

The pure colonies of isolated bacteria were selected with a sterilized toothpick, and suspended in $0.5 \mathrm{ml}$ of sterilized saline in $1.5 \mathrm{ml}$ centrifuge tube and were centrifuged at $10,000 \mathrm{rpm}$ for $10 \mathrm{~min}$. After removal of supernatant, the pellet was suspended in $0.5 \mathrm{ml}$ of InstaGene Matrix (Bio-Rad, USA) and incubated at $56^{\circ} \mathrm{C}$ for $30 \mathrm{~min}$ and then heated at $100^{\circ} \mathrm{C}$ for $10 \mathrm{~min}$. After heating, the supernatant can be used for polymerase chain reaction (PCR). $1 \mu \mathrm{l}$ of template DNA was added in $20 \mu \mathrm{l}$ of PCR reaction solution. 27F/1492R universal primers (1492R 5'TACGGYTACCTTGTTACGACTT3' 27F 5' AGAGTTTGATCMTGGCTCAG $\left.3^{\prime}\right)$ were used and 35 amplification cycles at $94^{\circ} \mathrm{C}$ for $45 \mathrm{~s}, 55^{\circ} \mathrm{C}$ for $60 \mathrm{~s}$, and $72^{\circ} \mathrm{C}$ for $60 \mathrm{~s}$ were performed. DNA fragments amplified were about $1400 \mathrm{bp}$ in the case of bacteria. Positive control (Escherichia coli genomic DNA) and a negative control in the PCR were included. Unincorporated PCR primers and dNTPs from PCR products were removed using the Montage PCR Clean up kit (Millipore). The purified PCR products were sequenced using BigDye Terminator Cycle Sequencing Kit (Applied Biosystems, USA). Sequencing products were resolved on an Applied Biosystems model 3730XL automated DNA sequencing system (Applied Biosystems, USA). The sequence was aligned and submitted to NCBI database using Clustal X software. The phylogenetic tree was constructed using the neighbor-joining tree making an algorithm of MEGA 7 and deposited in GeneBank with the accession number KX824759.

Identification of molecular base sequence report using Sequencher version 5.2 software (Gene codes Corp, MD, USA). The base frequency report indicates the percentage of nucleotides such as adenine, thymine, cytosine, and guanine in individuals. The report also showed the nucleotide frequency, dinucleotide frequency, and trinucleotide frequency percentage with different nucleotide combinations.

\section{Motility assay}

Motility of the strain was tested using a modified method [34], semisolid motility test medium (1\% agar) in $18 \mathrm{~mm} \times 150 \mathrm{~mm}$ glass culture tubes. The bacterial culture was inoculated into the medium using a sterile straight needle to one-half the depth of the tube. Tubes were incubated at $55^{\circ} \mathrm{C}$ for 3 days and results were observed at 24,48 , and $72 \mathrm{~h}$.

\section{Antibiotic resistance profile}

Drug resistance is the major difficulty of this era, which is leading toward morbidity and mortality [35]. Resistance to antibiotics was determined on PBTA media. The plates were amended at the following concentration in $\mathrm{mg} / \mathrm{ml}$ : Amoxicillin (10), norfloxacin (15), erythromycin (10), cefixime (5), cephalexin (10), and cefpodoxime (5). Plates were streaked with Geobacillus thermoleovorans KNG 112 and were incubated at $55^{\circ} \mathrm{C}$. The plates were observed daily for resistance up to 4 days.

\section{Partial optimization of amylase production}

Effect of temperature, $p H$, and carbon sources on amylase production

To study the effects of temperature and $\mathrm{pH}$ on enzyme production and growth of the organisms, the strain was grown in the basal media at different $\mathrm{pH}(5-10)$ and temperature $\left(30^{\circ} \mathrm{C}-85^{\circ} \mathrm{C}\right)$. The optimum temperature and $\mathrm{pH}$ for maximum enzyme production were obtained after working out a series of experiments for the bacterial strain. The different carbon sources such as lactose, starch, sucrose, maltose, and glucose were used for the production of amylase.

\section{Effect of agitation rate on amylase production}

The effect of agitation rate was determined by incubating the culture at $55^{\circ} \mathrm{C}$ with different agitation speed $80,100,120$, and $140 \mathrm{rpm}$. The bacterial growth was investigated spectrophotometrically at $600 \mathrm{~nm}$.

\section{Estimation of protein}

The protein concentration of culture filtrate was estimated by the Bradford method [36], bovine serum albumin was used as standard. $250 \mu \mathrm{l}$ of Bradford reagent was mixed with $50 \mu \mathrm{l}$ of appropriate diluted enzyme sample and incubated for $10 \mathrm{~min}$ at room temperature. Optical density was measured at $595 \mathrm{~nm}$ against a blank prepared with $50 \mu \mathrm{l}$ buffer. The standard curve was constructed using bovine serum albumin was a standard known protein.

\section{Amylase activity assay}

The amylase activity was determined by measuring the amount of reducing sugars released during starch hydrolysis using the dinitrosalicylic method [37]. The reaction mixture containing $0.5 \mathrm{ml}$ of $1 \%(\mathrm{w} / \mathrm{v}$ ) soluble starch in $20 \mathrm{mM}$ Tris- $\mathrm{HCl}, \mathrm{pH} 7.4$, and $0.5 \mathrm{ml}$ of enzyme solution was incubated for $30 \mathrm{~min}$ at $60^{\circ} \mathrm{C}$. The reaction was stopped by adding $1 \mathrm{ml}$ of DNS solution and the mixture was boiled for $10 \mathrm{~min}$. After cooling, the mixture was diluted 4 times with double distilled water and the absorbance at $540 \mathrm{~nm}$ was measured. One unit of enzyme activity was defined as the amount of enzyme that releases $1 \mu \mathrm{mol}$ of reducing sugar equivalent to maltose per minute.

\section{RESULTS AND DISCUSSION}

\section{Isolation of bacteria}

Initially, six strains were isolated from hot water sample. Based on their morphological characteristics, only three strains have shown both amylolytic and lipolytic activity. The selected strain was named as IC5 for further characterization. Species belonging to genus Geobacillus have been isolated from many natural hot springs [38,39].

\section{Biochemical identification of bacteria}

The isolated bacteria from hot spring water were found to be a member of Geobacillus and identified as Gram-positive, aerobe, and non-motile rods. Cells formed cream circular colonies with a diameter of 2.0$2.5 \mathrm{~mm}$ and smooth margins on PBTA medium at $60^{\circ} \mathrm{C}$. The temperature growth range was between 35 and $80^{\circ} \mathrm{C}$ with an optimum growth at $55^{\circ} \mathrm{C}$. The $\mathrm{pH}$ growth range was from 5.5 to 9.5 with an optimum $\mathrm{pH}$ 7.5. The isolate was grown on PBTA medium having $\mathrm{pH} 7.5$ at $60^{\circ} \mathrm{C}$ unless otherwise stated and subculturing was performed on the same medium. The isolate was maintained as a glycerol stock at $-70^{\circ} \mathrm{C}$ for further studies

The growth of isolate was observed up to $8 \% \mathrm{NaCl}(\mathrm{w} / \mathrm{v})$. The isolate utilized different carbon sources and shown positive results for D-cellobiose, glycerol, D-xylose and negative for D-galactose, inositol, and D-lactose. The isolates hydrolyzed starch and tributyrin and have not hydrolyzed casein and gelatin (Table 1). 
Molecular identification

Approximately 1080 bp 16s rRNA gene product was sequenced for the isolated bacteria. This sequence, containing $1140 \mathrm{bp}$ constituted, was by nucleotides with 1079 bp database query. 16S rRNA gene sequence of strain KNG 112 showed the highest homology (an identity of 99.9\%) to 16S rRNA gene sequence of G. kaustophilus C4. A phylogenetic tree was constructed using $16 \mathrm{~S}$ rRNA sequence of several microorganisms, which demonstrated that the closest neighbor of strain KNG 112 was G. thermoleovorans EC-5 (Fig. 4).

\section{Analysis of nucleotide frequency}

The partial sequences of $16 \mathrm{~s}$ rRNA gene of $G$. thermoleovorans KNG 112 strain containing nucleotide, dinucleotide, and trinucleotide frequency percentage were determined using sequencer software version 5.2 (Table 2).

Table 1: Comparative physiological characteristics of thermophilic Geobacillus thermoleovorans KNG 112 isolated from Bandaru hot spring with reference strains

\begin{tabular}{|c|c|c|c|c|}
\hline & $\begin{array}{l}G . \\
\text { KNG } 112\end{array}$ & $\begin{array}{l}\text { G. ththemondeenahminss } \\
\left(\mathrm{DSM} 730^{\mathrm{T}}\right)\end{array}$ & $\begin{array}{l}\text { G. thermodenitrificans } \\
\left(\mathrm{DSM} 466^{\mathrm{T}}\right)\end{array}$ & $\begin{array}{l}\text { G. thermoleovorans } \\
\left(\mathrm{DSM} 5366^{\mathrm{T}}\right)\end{array}$ \\
\hline pH range & $5.5-9.5$ & $6.5-8.5$ & $6.0-8.0$ & $6.2-7.8$ \\
\hline Optimum pH & 7.5 & $6.8-7.0$ & $6.8-7.0$ & $6.8-7.0$ \\
\hline Temperature range & $35^{\circ} \mathrm{C}-80^{\circ} \mathrm{C}$ & $42^{\circ} \mathrm{C}-69^{\circ} \mathrm{C}$ & $45^{\circ} \mathrm{C}-70^{\circ} \mathrm{C}$ & $35^{\circ} \mathrm{C}-78^{\circ} \mathrm{C}$ \\
\hline Optimum temperature & $55^{\circ} \mathrm{C}$ & $55^{\circ} \mathrm{C}-60^{\circ} \mathrm{C}$ & $55^{\circ} \mathrm{C}-60^{\circ} \mathrm{C}$ & $55^{\circ} \mathrm{C}-65^{\circ} \mathrm{C}$ \\
\hline Gram reaction & + & ND & ND & ND \\
\hline Shape of the cell & Rod & ND & ND & ND \\
\hline $\mathrm{NaCl}$ stability & $0 \%-8 \%$ & $0-5$ & $0-5$ & $0-4$ \\
\hline \multicolumn{5}{|l|}{ Hydrolysis test } \\
\hline Starch & + & - & - & + \\
\hline Casein & - & + & - & - \\
\hline Gelatin & - & - & - & - \\
\hline Tributyrin & + & ND & ND & ND \\
\hline \multicolumn{5}{|l|}{ Production of acids } \\
\hline D-Cellobiose & + & + & + & + \\
\hline Glycerol & + & + & - & + \\
\hline Inositol & - & ND & ND & ND \\
\hline D-Lactose & - & - & + & + \\
\hline D-Xylose & + & + & - & + \\
\hline
\end{tabular}

Detailed description of characteristic features of Taxa, 1. G. thermoleovorans KNG 112; 2. G. thermocatenulatus (DSM 730 ${ }^{\mathrm{T}}$ ); 3. G. thermodenitrificans (DSM 466 ${ }^{\mathrm{T}}$ );

4. G. thermoleovorans (DSM 5366 ). G. thermoleovorans: Geobacillus thermoleovorans, G. thermodenitrificans: Geobacillus thermodenitrificans, ND:

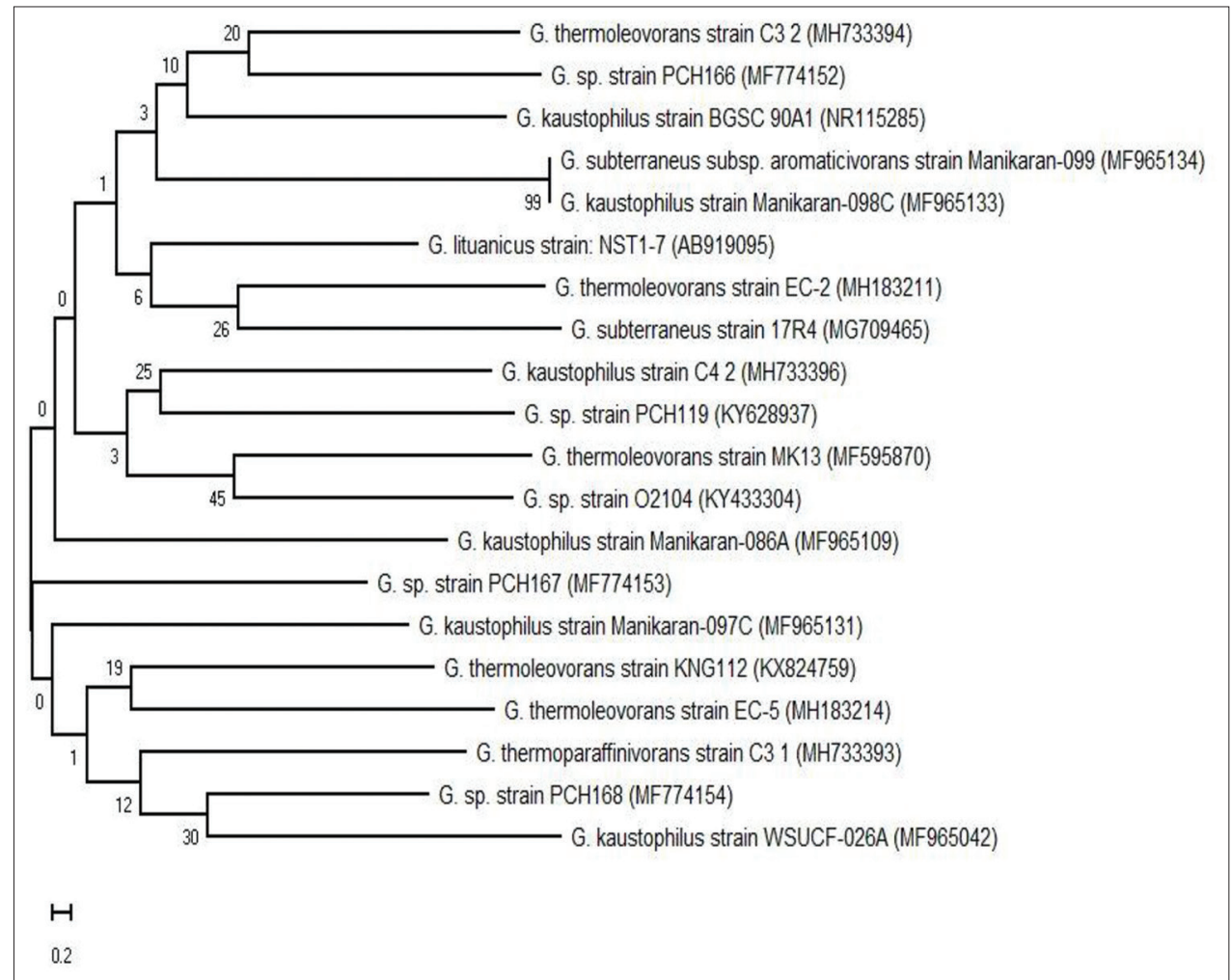

Fig. 4: Evolutionary relationships of the selected hot spring isolated strain 16s rRNA gene sequences with publically associated taxa. Phylogram was inferred using the neighbor-joining method. The percentage of replicate trees in which the associated taxa clustered together in the bootstrap tests (500 replicates), is indicated at branching points 
Table 2: Nucleotide frequency, dinucleotide frequency, trinucleotide frequency percentage with different nucleotide combinations of 16s rRNA sequence of Geobacillus thermoleovorans KNG 112

\begin{tabular}{|l|r|r|}
\hline Base & Total & $\%$ \\
\hline A & 246 & 22.80 \\
\hline C & 272 & 25.21 \\
\hline G & 372 & 34.48 \\
\hline T & 189 & 17.52 \\
\hline Ambiguity & 0 & 0.00 \\
\hline
\end{tabular}

\begin{tabular}{|l|r|l|l|r|l|l|r|r|r|r|r|}
\hline Base & Total & $\%$ & Base & Total & $\%$ & Base & Total & $\%$ & Base & Total & $\%$ \\
\hline AA & 69 & 6.40 & CA & 55 & 5.10 & GA & 85 & 7.88 & TA & 37 & 3.43 \\
\hline AC & 63 & 5.84 & CC & 71 & 6.59 & बC & 98 & 9.09 & TC & 40 & 3.71 \\
\hline AG & 84 & 7.79 & CG & 94 & 8.72 & GG & 121 & 11.22 & TG & 72 & 6.68 \\
\hline AT & 29 & 2.69 & CT & 52 & 4.82 & GT & 68 & 6.31 & TT & 40 & 3.71 \\
\hline
\end{tabular}

\begin{tabular}{|l|r|r||l|r|r|l|l|l|l|r|r|}
\hline Base & Total & $\%$ & Base & Total & $\%$ & Base & Total & $\%$ & Base & Total & $\%$ \\
\hline AAA & 14 & 1.30 & CAA & 15 & 1.39 & GAA & 24 & 2.23 & TAA & 16 & 1.49 \\
\hline AAC & 20 & 1.86 & CAC & 16 & 1.49 & GAC & 19 & 1.76 & TAC & 8 & 0.74 \\
\hline AAG & 25 & 2.32 & CAG & 17 & 1.58 & GAG & 30 & 2.79 & TAG & 12 & 1.11 \\
\hline AAT & 10 & 0.93 & CAT & 7 & 0.65 & GAT & 11 & 1.02 & TAT & 1 & 0.09 \\
\hline ACA & 12 & 1.11 & CCA & 12 & 1.11 & GCA & 21 & 1.95 & TCA & 10 & 0.93 \\
\hline ACC & 17 & 1.58 & CCC & 18 & 1.67 & GCC & 24 & 2.23 & TCC & 12 & 1.11 \\
\hline ACG & 23 & 2.14 & CCG & 23 & 2.14 & GCG & 38 & 3.53 & TCG & 10 & 0.93 \\
\hline ACT & 11 & 1.02 & CCT & 18 & 1.67 & GCT & 15 & 1.39 & TCT & 8 & 0.74 \\
\hline AGA & 16 & 1.49 & CGA & 17 & 1.58 & GGA & 29 & 2.69 & TGA & 23 & 2.14 \\
\hline AGC & 28 & 2.60 & CGC & 25 & 2.32 & GGC & 32 & 2.97 & TGC & 13 & 1.21 \\
\hline AGG & 27 & 2.51 & CGG & 33 & 3.06 & GGG & 37 & 3.44 & TGG & 24 & 2.23 \\
\hline AGT & 13 & 1.21 & CGT & 19 & 1.76 & GGT & 23 & 2.14 & TGT & 12 & 1.11 \\
\hline ATA & 6 & 0.56 & CTA & 8 & 0.74 & GTA & 14 & 1.30 & TTA & 9 & 0.84 \\
\hline ATC & 2 & 0.19 & CTC & 14 & 1.30 & GTC & 15 & 1.39 & TTC & 9 & 0.84 \\
\hline ATG & 11 & 1.02 & CTG & 18 & 1.67 & GTG & 26 & 2.41 & TTG & 17 & 1.58 \\
\hline ATT & 10 & 0.93 & CTT & 12 & 1.11 & GTT & 13 & 1.21 & TTT & 5 & 0.46 \\
\hline
\end{tabular}

Starch and lipid degradation

The genus Geobacillus produces a large variety of extracellular enzymes; amylases are particularly considered for industrial importance [40]. This study deals with the screening of amylolytic and lipolytic enzymeproducing bacteria and production condition optimization and partial characterization of crude extracellular amylase produced by novel G. thermoleovorans KNG 112. G. thermoleovorans KNG 112 amylase activity was monitored on starch agar media. After $24 \mathrm{~h}$ of incubation, clear zone was observed around the strain after flooding iodine solution (Fig. 5).

For lipid degradation, the strain produced clear zone around the colonies on the tributyrin agar medium. The agar plates containing olive oil and Rhodamine B have pinkish color and an impervious appearance. Lipase production was observed by irradiating plates with UV light at $350 \mathrm{~nm}$. After $48 \mathrm{~h}$ of incubation, colonies have shown orange fluorescent halos around the colonies of lipase producing strains after longer incubation. IC5 showed a fluorescent halo (Fig. 6). It has been recognized that Geobacillus species can degrade various triacylglycerol.

Effect of temperature, $\mathrm{pH}$, and carbon sources on amylase production

The extracellular amylase production of the bacterium was studied in SYBT broth media. In our study, G. thermoleovorans KNG112 has shown maximum activity at $55^{\circ} \mathrm{C}$, where $30^{\circ} \mathrm{C}-80^{\circ} \mathrm{C}$ temperature ranges were also been observed. Most of the Geobacillus species were shown maximum activity at $55^{\circ} \mathrm{C}-70^{\circ} \mathrm{C}$. The same optimum temperature was also observed in the optimization of amylase production from Anoxybacillus flavithermus [41]. In the series of $\mathrm{pH}$ ranges 5-10, the maximum amylase production was achieved at pH 7.5 (Table 3).

Further studies on enzyme production in shake-flask cultures were carried out using G. thermoleovorans KNG 112. The organism was used for extracellular amylase production in shake-flask culture using PBTA media $0.1 \%$ yeast extract, $0.25 \%$ peptone, $0.1 \%$ beef extract, $0.005 \% \mathrm{MgSO}_{4} .0 .005 \% \mathrm{CaCl}_{2}$, and $2 \%$ soluble starch, $\mathrm{pH}-7.5$ ] [30], for $36 \mathrm{~h}$ of incubation at $55^{\circ} \mathrm{C}$ and enzyme activity obtained was $0.76 \mathrm{U} / \mathrm{ml}$. To enhance the production of the enzyme,

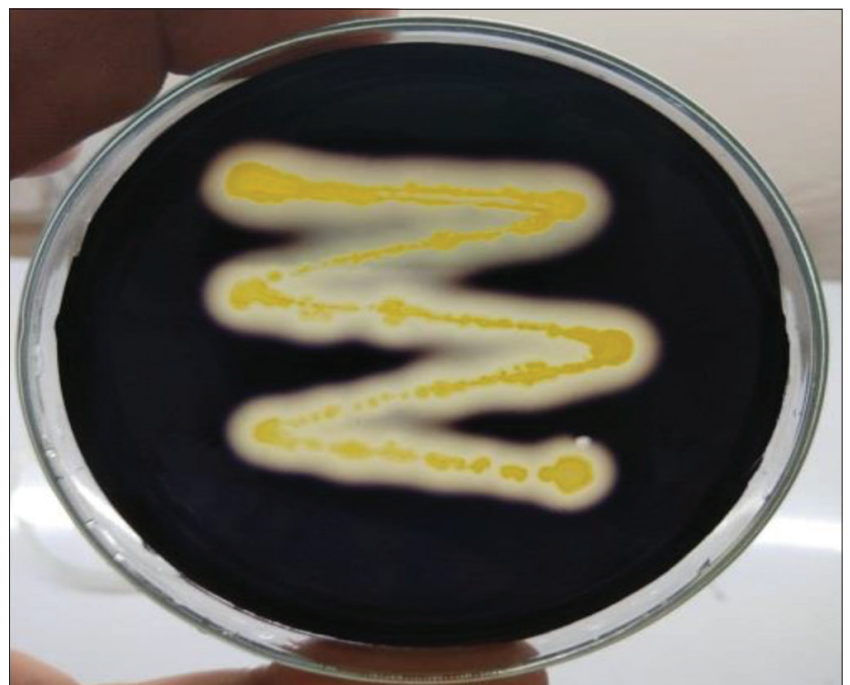

Fig. 5: The amylase production capability test of newly isolated Geobacillus was done by starch hydrolysis on the starch agar plate assay method. Bacterial isolate was streaked on the starch agar plate and plates were incubated at $55^{\circ} \mathrm{C}$ for $24 \mathrm{~h}$.

various parameters associated with the production of amylase were studied in the medium used for the enzyme production. Optimization of culture conditions is very important for maximum microbial growth and enzyme production by microorganisms [42]. Among the physical and chemical parameters, optimum temperature, $\mathrm{pH}$ range, carbon and nitrogen sources are most important for enzyme production by microbes [43]

The time course in shake culture fermentation, the maximum rate of enzyme production was increased with the increase in the fermentation period and the maximum activity was reached after $36 \mathrm{~h}$ of incubation (Table 3). At that time, protein concentration obtained was $3.51 \mathrm{mg} / \mathrm{ml}$.

From the time course study in shake culture, it was found that the rate of enzyme production was increased with the increase in the 
Table 3: Effect of culture condition for extracellular amylase production from Geobacillus thermoleovorans KNG 112

\begin{tabular}{|c|c|c|c|}
\hline Culture condition & Amylase activity $(\mathrm{U} / \mathrm{ml})$ & Relative activity (\%) & Total soluble protein $(\mathrm{mg} / \mathrm{ml})$ \\
\hline \multicolumn{4}{|l|}{ Initial pH } \\
\hline 5 & 0.32 & 26.67 & 0.75 \\
\hline 5.5 & 0.53 & 44.64 & 0.98 \\
\hline 6 & 0.77 & 64.84 & 1.13 \\
\hline 6.5 & 0.83 & 72.78 & 1.21 \\
\hline 7 & 1.12 & 93.29 & 1.94 \\
\hline 7.5 & 1.20 & 100.00 & 2.17 \\
\hline 8.5 & 0.83 & 69.54 & 2.11 \\
\hline 9 & 0.73 & 61.06 & 1.89 \\
\hline 9.5 & 0.56 & 46.95 & 1.75 \\
\hline 10 & 0.39 & 33.07 & 1.69 \\
\hline \multicolumn{4}{|c|}{ Incubation temperature } \\
\hline 30 & 0.36 & 50.12 & 1.21 \\
\hline 37 & 0.43 & 55.68 & 1.85 \\
\hline 45 & 0.80 & 92.34 & 2.21 \\
\hline 65 & 0.81 & 93.09 & 1.68 \\
\hline 70 & 0.67 & 77.47 & 1.58 \\
\hline 75 & 0.63 & 72.68 & 1.14 \\
\hline \multicolumn{4}{|l|}{ Incubation period } \\
\hline 12 & 0.63 & 71.09 & 2.56 \\
\hline 24 & 0.73 & 91.34 & 3.51 \\
\hline 36 & 0.76 & 100 & 3.42 \\
\hline 50 & 0.66 & 86.24 & 3.22 \\
\hline 60 & 0.57 & 71.09 & 3.03 \\
\hline 90 & 0.47 & 69.92 & 2.94 \\
\hline
\end{tabular}
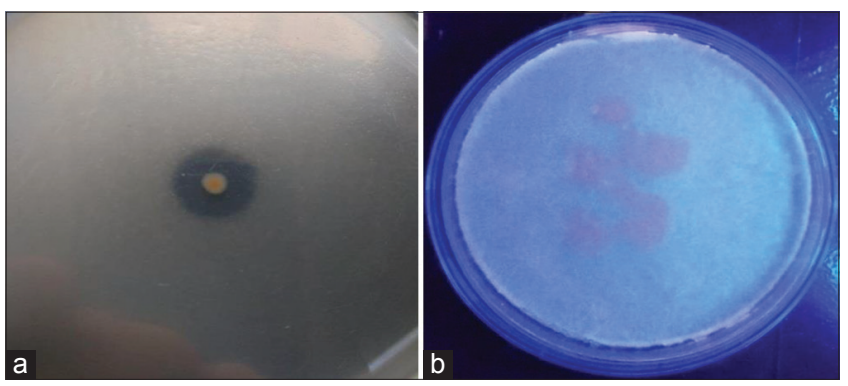

Fig. 6: Zone of clearance due to the hydrolysis of tributyrin on TA media by isolated Geobacillus species, the plate was incubated at $55^{\circ} \mathrm{C}$ for $24 \mathrm{~h}$. The isolate has shown orange halos under ultraviolet light at $350 \mathrm{~nm}$, which indicates the isolate was capable to produce lipase on olive oil Rhodamine B agar media.

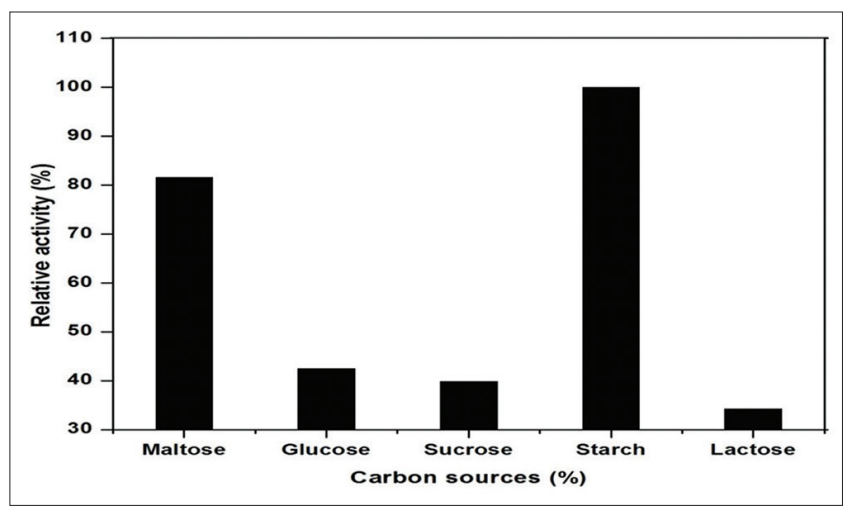

Fig. 7: The effect of different carbon sources on enzyme production was studied using loopfull of inoculum in $100 \mathrm{ml}$ basal medium. The fermentation was carried out at $55^{\circ} \mathrm{C}$ at $120 \mathrm{rpm}$ for $40 \mathrm{~h}$. Absorbance was measured at $540 \mathrm{~nm}$ with spectrophotometer and enzyme activity was presented on the $y$ axis and carbon sources was on $\mathrm{X}$-axis

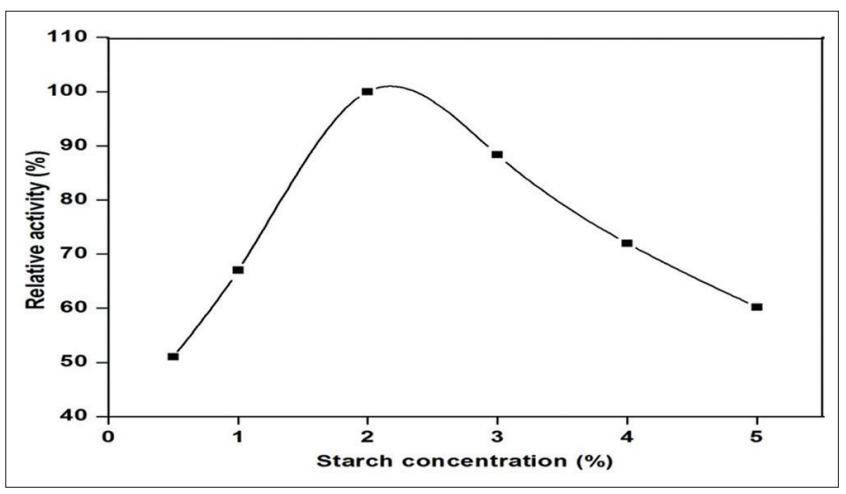

Fig. 8: The effect of starch concentration on the amylase production by Geobacillus thermoleovorans $\mathrm{KNG} 112$ at $55^{\circ} \mathrm{C}$ and pH 7.5 in shake flask culture

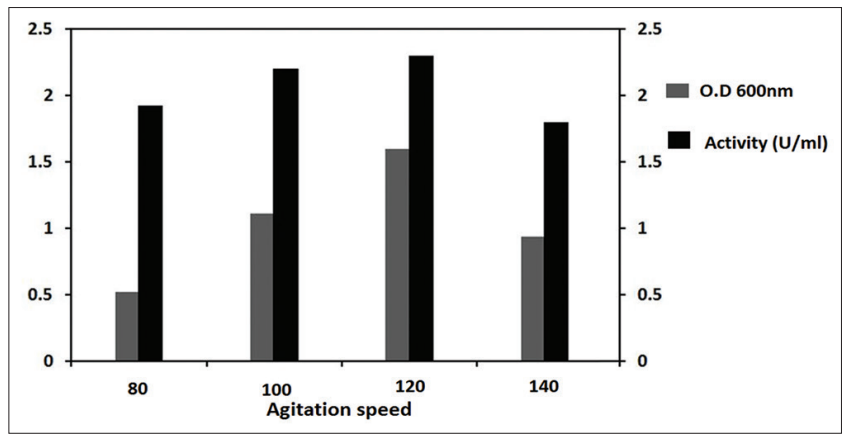

Fig. 9: Effect of agitation speed on amylase production

fermentation period and reached its maximum activity after $48 \mathrm{~h}$ incubation (Table 3).

Fig. 8 shows the effect of starch concentration, maximum amylase production was at $2 \%$. The maximum extracellular amylase was 


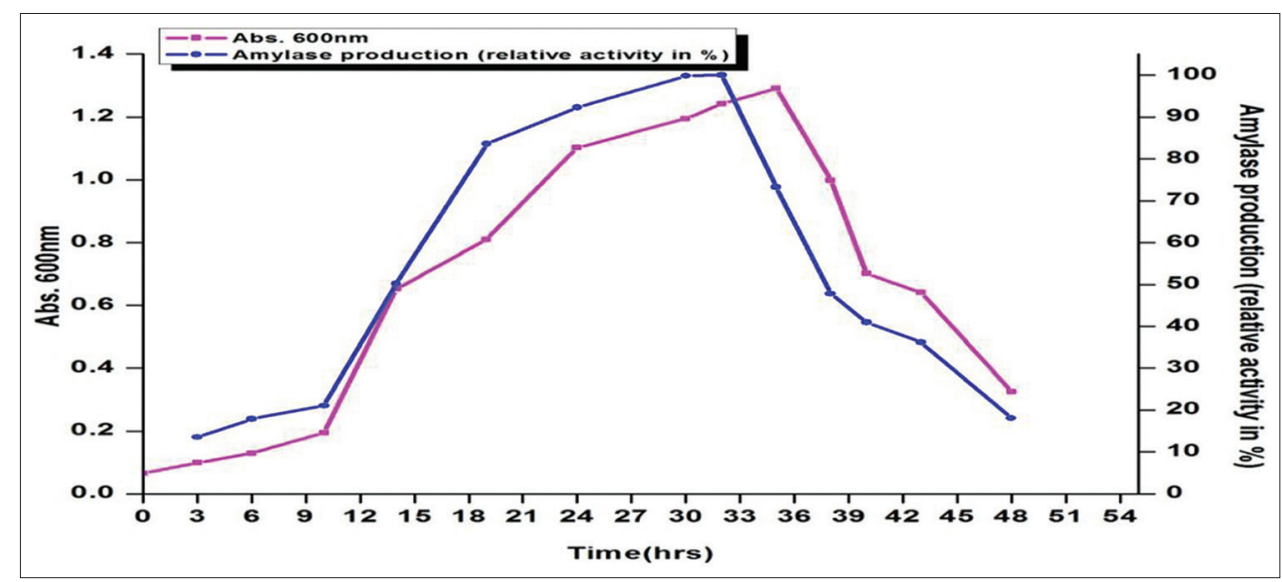

Fig. 10: Amylase was produced at various stages of bacterial growth in SYBT media and was incubated at $55^{\circ} \mathrm{C}$ and $\mathrm{pH}$ of 7.5 . The activity was assayed in the supernatant of culture. The optical density of bacterial growth was measured at $600 \mathrm{~nm}$ using biospectrophotometer

produced with an increase in the starch concentration up to $2 \%$. At higher concentration (more than $2 \%$ ) of starch, the production of amylase was decreased, same results were obtained for the production of $\alpha$-amylase by an extreme thermophile Bacillus thermoleovorans NP54 [44].

Fig. 9 shows that the maximum production of amylase was at $120 \mathrm{rpm}$ speed. The data exposed that shaking is very essential for production of amylase; enzyme production was declined after shaking speed reaches $150 \mathrm{rpm}$ due to the damage of bacterial cell at higher shaking speed [45].

\section{Antibiotic susceptibility}

The growth performance of $G$. thermoleovorans KNG 112 was studied in the presence of a variety of antibiotics. The strain was susceptible to cephalexin $(10 \mathrm{mg} / \mathrm{ml})$, and resistant to norfloxacin (15), erythromycin (10), cefixime (5), and cefpodoxime (5).

\section{CONCLUSION}

The thermophilic novel bacteria G. thermoleovorans KNG 112 was isolated and primary enzymatic production potential was determined and characterized. This is the first investigation describing the isolation and characterization of novel Geobacillus strain from Bandaru hot spring Karnataka, India. The diversity in phenotypic and enzymatic analysis among G. thermoleovorans strains indicated the presence of subspecies. These capable results can be exploited further for production of industrially viable thermostable enzymes. The present study envisages the capability of thermophilic bacteria G. thermoleovorans KNG 112 for the production of biotechnologically important amylolytic and lipolytic thermo stable enzymes. The optimal condition of the amylase production was achieved at $55^{\circ} \mathrm{C}$ and $\mathrm{pH}-7.5$, while $2 \%$ starch achieved maximum amylase production and $120 \mathrm{rpm}$ agitation speed. The maximum growth and amylase production was recorded for $36 \mathrm{hrs}$ of incubation.

\section{ACKNOWLEDGMENT}

The authors would like to express his gratitude to the Department of P. G. Studies and Research in Biochemistry, Kuvempu University, for financial support to conduct this study.

\section{AUTHOR'S CONTRIBUTIONS}

The authors declare that this work was done by the authors named in this article.

\section{CONFLICTS OF INTEREST}

The authors declare that there are no conflicts of interest regarding the publication of this paper.

\section{REFERENCES}

1. Mori K, Kim H, Kakegawa T, Hanada S. A novel lineage of sulfatereducing microorganisms: Thermodesulfobiaceae fam. nov., Thermodesulfobium narugense, gen. nov., sp. nov., a new thermophilic isolate from a hot spring. Extremophiles 2003;7:283-90.

2. Chien A, Edgar DB, Trela JM. Deoxyribonucleic acid polymerase from the extreme thermophile Thermus aquaticus. J Bacteriol 1976;127:1550-7.

3. Bjornsdottir SH, Petursdottir SK, Hreggvidsson GO, Skirnisdottir S, Hjorleifsdottir S, Arnfinnsson J, et al. Thermus islandicus sp. nov., a mixotrophic sulfur-oxidizing bacterium isolated from the Torfajokull geothermal area. Int J Syst Evol Microbiol 2009;59:2962-6.

4. Everroad RC, Otaki H, Matsuura K, Haruta S. Diversification of bacterial community composition along a temperature gradient at a thermal spring. Microbes Environ 2012;27:374-81.

5. Ferrer M, Golyshina $\mathrm{O}$, Beloqui $\mathrm{A}$, Golyshin PN. Mining enzymes from extreme environments. Curr Opin Microbiol 2007;10:207-14.

6. Elizabeth $\mathrm{AB}$, Isaac DW, Juergen W. Thermal environments and biodiversity. Physiology and Biochemistry Extremophiles Washington DC: ASM; 2007. p. 13-29.

7. Michael TM, John M, Dunlap PV, Clark DP. Brock biology of microorganisms. Int Microbiol 2008;11:65-73.

8. Power JF, Carere CR, Lee CK, Wakerley GLJ, Evans DW, Button M, et al. Microbial biogeography of 925 geothermal springs in New Zealand. Nat Commun 2018;9:2876.

9. Mohammad BT, Al Daghistani HI, Jaouani A, Abdel-Latif S, Kennes C. Isolation and characterization of thermophilic Bacteria from Jordanian hot springs: Bacillus licheniformis and Thermomonas hydrothermalis isolates as potential producers of thermostable Enzymes. Int J Microbiol 2017;2017:6943952.

10. Johnson DB, Okibe N, Roberto FF. Novel thermo-acidophilic bacteria isolated from geothermal sites in Yellowstone National Park: Physiological and phylogenetic characteristics. Arch Microbiol 2003; $180: 60-8$.

11. Stefania P, Federica V, Vincenzo R, Annalisa BP, Isabella M. Microbial biodiversity of thermal water and mud in an Italian spa by metagenomics: A pilot study. Water Sci Technol Water Supply 2017;18:1456-65.

12. Adiguzel A, Ozkan H, Baris O, Inan K, Gulluce M, Sahin F. Identification and characterization of thermophilic Bacteria isolated from hot springs in Turkey. J Microbiol Methods 2009;79:321-8.

13. Satpal SB, Nagendra ND, Tripathy NK. Indian hot-water springs: A bird's eye view. J Energy Environ Carbon Credit 2016;1:1-15.

14. Caccamo D, Gugliandolo C, Stackebrandt E, Maugeri TL. Bacillus vulcani sp. nov., a novel thermophilic species isolated from a shallow marine hydrothermal vent. Int J Syst Evol Microbiol 2000;50:2009-12.

15. Miquel P. Monographie d'un bacille vivant au-dela de $70{ }^{\circ} \mathrm{C}$. Ann Microgr 1888;1:3.

16. Sen SK, Raut S, Satpathy S, Rout PR, Bandyopadhyay B, Das Mohapatra PK. Characterizing novel thermophilic amylase producing bacteria from taptapani hot spring, Odisha, India. Jundishapur J Microbiol 2014;7:e11800.

17. Thippeswamy S, Girigowda K, Mulimani VH. Isolation and identification of alpha-amylase producing Bacillus sp. from dhal industry waste. Indian J Biochem Biophys 2006;43:295-8. 
18. Sivaramakrishnan S, Gangadharan D, Nampoothiri KM, Soccol CR, Pandey A. $\alpha$-Amylases from microbial sources-an overview on recent developments. Food Technol. Biotechnol 2006;44:173-84

19. Arikan B. Highly thermostable, thermophilic, alkaline, SDS and chelator resistant amylase from a thermophilic Bacillus sp. isolate A3-15. Bioresour Technol 2008;99:3071-6.

20. Takasaki Y. An amylase producing maltotetraose and maltopentaose from Bacillus circulans. Agric Biol Chem 1983;47:2193-9.

21. Messaoud EB, Ali MB, Elleuch N, Masmoudi NF, Bejar S. Purification and properties of a maltoheptaose-and maltohexaose forming amylase produced by Bacillus subtilis US116. Enzyme Microb Technol 2004;34:662-6.

22. Sujata DB. Screening of nutritional components for $\alpha$-amylase production in submerged fermentation by bacteria isolated from soil using placket-burman design. Int J Pharm Pharm Sci 2010;2:93-8.

23. Kirk O, Borchert TV, Fuglsang CC. Industrial enzyme applications. Curr Opin Biotechnol 2002;13:345-51.

24. Palacios HR, Schwarz PB, D'Appolonia BL. Effect of alpha-amylases from different sources on the retrogradation and recrystallization of concentrated wheat starch gels: Relationship to bread staling. J Agric Food Chem 2004;52:5978-86.

25. Rajagopalan G, Krishnan C. Alpha-amylase production from catabolite derepressed Bacillus subtilis KCC103 utilizing sugarcane bagasse hydrolysate. Bioresour Technol 2008;99:3044-50.

26. Reddy NS, Nimmagadda A, Rao KR. An overview of the microbial $\alpha$-amylase family. Afr J Biotechnol 2003;2:645-8.

27. Viviána N, Eniko RT, Lee CK, Gábor S, Darah I, Ibrahim CO, et al. Kinetic resolutions with novel, highly enantioselective fungal lipases produced by solid state fermentation. J Mol Catal B 2006;39:141-8.

28. Niehaus F, Bertoldo C, Kähler M, Antranikian G. Extremophiles as a source of novel enzymes for industrial application. Appl Microbiol Biotechnol 1999;51:711-29.

29. Sharma R, Chisti Y, Banerjee UC. Production, purification, characterization, and applications of lipases. Biotechnol Adv 2001;19:627-62.

30. Rubin B, Dennis EA. Lipases: Part B. Enzyme characterization and utilization. Methods in Enzymol 1997;286:3-563.

31. Gurumurthy DM, Neelagund SE. Molecular characterization of industrially viable extreme thermostable novel $\alpha$-amylase of Geobacillus sp. Iso5 isolated from geothermal spring. J Pure Appl Microbiol 2012;6:1-6.

32. Ertuğrul S, Dönmez G, Takaç S. Isolation of lipase producing
Bacillus sp. from olive mill wastewater and improving its enzyme activity. J Hazard Mater 2007;149:720-4.

33. Davender K, Lalit K, Sushil N, Chand R, Rajinder P, Vijay KG. Screening, isolation and production of lipase/esterase producing Bacillus sp. strain DVL2 and its potential evaluation in esterification and resolution reactions. Arch Appl Sci Res 2012;4:1763-70.

34. Tittsler RP, Sandholzer LA. The use of semi-solid agar for the detection of bacterial motility. J Bacteriol 1936;31:575-80.

35. Monika M, Anju G. Synthesis and anti-microbial activity of 1-(6-nitro2h-benzo[b] [1,4] thiazine 3(4h)-ylidene) hydrazine-1,1-dioxide derivatives. Int J Pharm Pharm Sci 2016;8:178-82.

36. Bradford M. A rapid and sensitive method for the quantitation of microgram quantities of protein utilizing the principle of protein-dye binding. Anal Biochem 1976;72:248-54.

37. Bernfeld P. Amylase $\alpha$ and $\beta$ amylases. Methods Enzymol 1955;1:149-58.

38. Tamara NN, Elena VL, Andrei BP, Tourova T, Alexandre AG, Diyana SS, et al. Geobacillus gargensis sp. nov., a novel thermophile from a hot spring, and the reclassification of Bacillus vulcani as Geobacillus vulcani comb. nov. Int J Syst Evol Microbiol 2004;54:2019-24.

39. Avinash S, Anita P, Yogesh SS, Bhavesh K, Girish K. Characterization and identification of Geobacillus sp. isolated from soldhar hot spring site of Garhwal Himalaya, India. J Basic Microbiol 2009;49:187-94.

40. Manas RS, Shakthimay K, Gourikutti P, Ramesh CR. Partial characterization and optimization of production of extracellular amylase from Bacillus subtilis isolated from culturable cow dung microflora. Pol J Microbiol 2006;55:289-96.

41. Agüloğlu Fincan S, Enez B, Özdemir S, Matpan Bekler F. Purification and characterization of thermostable $\alpha$-amylase from thermophilic anoxybacillus flavithermus. Carbohydr Polym 2014;102:144-50.

42. Kathiresan K, Manivannan S. Cellulose production by Penicillium fellutanum isolated from coastal mangrove rhizosphere soil. Res J Microbiol 2006;1:438-42.

43. Bose K, Das D. Thermostable alpha-amylase production using Bacillus licheniformis NRRL B14368. Indian J Exp Biol 1996;34:1279-82.

44. Malhotra R, Noorwez SM, Satyanarayana T. Production and partial characterization of thermostable and calcium-independent alphaamylase of an extreme thermophile Bacillus thermooleovorans NP54. Lett Appl Microbiol 2000;31:378-84.

45. Simair AA, Qureshi AS, Khushk I, Ali CH, Lashari S, Bhutto MA, et al. Production and partial characterization of $\alpha$-amylase enzyme from Bacillus sp. BCC 01-50 and potential applications. Biomed Res Int 2017;2017:9173040. 